\title{
STANDAR PENGATURAN PELINDUNGAN TEKNOLOGI SENSITIF KEANTARIKSAAN INTERNASIONAL: IMPLEMENTASI DI INDONESIA
}

\author{
Runggu Prilia Ardes ${ }^{a}$
}

\begin{abstract}
ABSTRAK
Undang-Undang Republik Indonesia Nomor 21 Tahun 2013 tentang Keantariksaan mengamanatkan Indonesia untuk menguasai teknologi keantariksaan secara mandiri. Namun, pemenuhan tujuan tersebut tidak mudah karena teknologi keantariksaan bersifat sensitif sehingga persebarannya dilindungi dan dibatasi oleh negara-negara maju. Wujud pelindungan tersebut adalah rezim pengendalian ekspor yang pada dasarnya bersifat soft law (hukum lunak), namun dalam penerapannya mengikat secara mutlak. Indonesia tengah menyusun sebuah Peraturan Pemerintah dengan harapan dapat meyakinkan negara-negara maju bahwa teknologi mereka akan aman di Indonesia. Tulisan ini hendak menganalisis bagaimana standar pengaturan pelindungan teknologi sensitif di negara-negara dan apakah ada kesenjangan antara praktik negara-negara dengan di Indonesia, dengan menggunakan metode perbandingan yaitu membandingkan peraturan di negara-negara (Uni Eropa dan Tiongkok) dengan peraturan Indonesia. Hasil analisis menunjukkan standar pengaturan pelindungan teknologi sensitif di negara-negara umumnya memuat (i) konsep pelindungan teknologi; (ii) penerapan rezim pengendalian ekspor internasional; (iii) daftar teknologi sensitif keantariksaan dan prinsip catch-all; (iv) perizinan dan penilaian; serta (v) pengawasan. Tulisan ini juga menemukan adanya kesenjangan antara standar tersebut dengan rancangan Peraturan Pemerintah di Indonesia.
\end{abstract}

Kata kunci: pelindungan teknologi; pengendalian ekspor; teknologi sensitif.

\section{ABSTRACT}

Law of the Republic of Indonesia Number 21 Year 2013 concerning Space Activities mandates Indonesia to master space technology independently. However, fulfilling these objectives is difficult because space technology is sensitive so that its distribution is protected and limited by developed countries. Such form of protection is export control regimes which is basically soft law but, in its application, is absolutely binding. Indonesia is currently drafting a Government Regulation in the hope of convincing developed countries that their technology will be safe in Indonesia. This paper intends to analyze how the standards for the regulation of the protection of sensitive technology in some States and whether there is a gap between such practices and in Indonesia, with comparative method which is comparing existing regulations in several States (European Union and China) with Indonesian regulations. The result of the analysis shows that the regulatory standards for sensitive technology protection in States generally consist of (i) the concept of technological protection; (ii) implementation of international export control regimes; (iii) list of space-sensitive technologies and the catch-all principle; (iv) licensing and assessment; and (v) supervision. This paper also finds gaps between these standards and the draft Government Regulation in Indonesia.

Keywords: export control; sensitive technology; technology protection.

\footnotetext{
a Peneliti Muda Pusat Kajian Kebijakan Penerbangan dan Antariksa, LAPAN, Jl. Cisadane No. 25, Jakarta 10330, email: rungguprilia@gmail.com.
} 


\section{PENDAHULUAN}

Teknologi keantariksaan bersifat guna ganda atau dual-use. Hal ini berangkat dari fakta bahwa teknologi-teknologi mendasar dalam benda antariksa (roket, satelit, beserta sistemnya) dapat digunakan untuk kegiatan sipil dan militer. Penginderaan jauh dapat dimanfaatkan untuk mengumpulkan data intelijen, sistem navigasi digunakan untuk mengarahkan peledak atau mengirimkan senjata misil. ${ }^{1}$ Sifat guna ganda ini pula yang mendorong banyak negara untuk menguasai teknologi antariksa. Menyadari hal-hal tersebut, teknologi keantariksaan kerap dikatakan sensitif dan dapat mengancam keamanan apabila disalahgunakan.

Sensitifitas teknologi keantariksaan memicu berbagai negara, terutama negara maju, untuk melindungi dan mengawasi persebaran teknologi mereka melalui pemberlakuan rezim pengendalian ekspor. Rezim tersebut di antaranya adalah Nuclear Suppliers Group 1974 ("NSG"), Australia Group 1985 ("AG"), Missile Technology Control Regime 1987 ("MTCR"), dan the Wassenaar Arrangement on Export Controls for Conventional Arms and Dual-Use Goods and Technologies 1996 ("Wassenaar Arrangement" atau "WA"). Pada dasarnya rezim hanya mengikat para pihak atau anggotanya, namun pada penerapannya rezim pengendalian ekspor secara tidak langsung berdampak ke luar.

Dampak penerapan rezim tersebut turut dirasakan oleh Indonesia. Sedari dulu Indonesia bercita-cita untuk menguasai teknologi keantariksaan agar tidak terus bergantung pada negara lain. Keinginan ini terdapat dalam Undang-Undang RI Nomor 21 Tahun 2013 tentang Keantariksaan. Bahkan dalam Rencana Induk keantariksaan, pada tahun 2040, Indonesia memiliki target untuk meluncurkan satelit sendiri dengan roket sendiri. Meski demikian, pemenuhan keinginan tersebut tidak mudah karena Indonesia belum mampu untuk memproduksi teknologi antariksa secara mandiri. Pembelian teknologi dari negara lain juga tidak mudah karena kerap terbentur oleh rezim pengendalian ekspor. Sebagai contoh, saat ini Indonesia hanya mampu memproduksi propelan untuk bahan peledak. Propelan untuk roket memiliki karakteristik berbeda dan kompleksitas yang tinggi. Di sisi lain, sulit bagi Indonesia untuk membeli bahan baku propelan roket karena negara pemilik material tersebut umumnya tergabung dalam rezim, dan bahan tersebut masuk ke dalam daftar teknologi yang dilindungi. ${ }^{2}$ Akibatnya, Indonesia kesulitan untuk mengembangkan program roketnya dan pengembangan kemampuan teknologi keantariksaan Indonesia pun terhambat.

\footnotetext{
${ }^{1}$ Cassandra Steer, "Global Commons, Cosmic Commons: Implications of Military and Security Uses of Outer Space", Georgetown Journal of International Affairs, No. 1, Vol. 18, 2017, hlm. 9.

2 Dini Susanti et. al, "Missile Technology Control Regime (MTCR): Manfaat dan Konsekuensi Keanggotaan Indonesia", dalam: Husni Nasution, Euis Susilawati, Mardianis (eds), Kajian Kebijakan Penerbangan dan Antariksa, In Media, Bogor: 2018 , hlm. 84.
} 
Standar Pengaturan Pelindungan Teknologi Sensitif Keantariksaan Internasional: Implementasi di Indonesia

Saat ini Indonesia tengah menyusun Rancangan Peraturan Pemerintah tentang Penguasaan Teknologi Keantariksaan (“RPP Penguasaan Teknologi Keantariksaan”). RPP ini bertujuan untuk mempercepat penguasaan teknologi keantariksaan Indonesia dan untuk membuka akses alih teknologi baik dari lokal maupun asing. Dalam rangka alih teknologi tersebut, RPP ini menyinggung perihal pelindungan teknologi keantariksaan sensitif yang materi muatannya ditujukan untuk memenuhi kewajiban rezim pengendalian ekspor di tingkat internasional. Status terkini dari naskah RPP Penguasaan Teknologi Keantariksaan adalah telah melewati tahap harmonisasi dan sedang menunggu paraf persetujuan dari Kementerian/Lembaga terkait untuk selanjutnya disahkan oleh Presiden.

Dalam rangka pemenuhan tujuan tersebut, maka rumusan masalah tulisan ini adalah bagaimana konsep pengaturan pelindungan teknologi sensitif keantariksaan di negara-negara (Uni Eropa dan Republik Rakyat Tiongkok), dan apakah ada kesenjangan antara peraturan-peraturan tersebut dengan rancangan peraturan pemerintah di Indonesia. Tulisan ini bertujuan untuk melihat kesenjangan antara pengaturan pelindungan teknologi sensitif di Indonesia dengan negara-negara lain. Dengan demikian, model pengaturan pelindungan teknologi sensitif yang ideal dapat ditemukan.

\section{METODE PENELITIAN}

Kajian ini menggunakan metode komparasi yaitu membandingkan antara peraturan suatu negara dengan negara lainnya mengenai hal yang sama. Penggunaan metode ini bertujuan untuk memperoleh persamaan dan perbedaan di antara peraturan-peraturan tersebut. ${ }^{3}$ Penelitian ini menggunakan data sekunder seperti bahan hukum primer (peraturan perundang-undangan nasional dan internasional) dan bahan hukum sekunder (buku, jurnal, makalah, dan artikel).

\section{PEMBAHASAN}

\section{Pelindungan Teknologi Sensitif dan Rezim Pengendalian Ekspor}

Pelindungan teknologi sensitif tidak diatur secara khusus dalam traktat-traktat keantariksaan internasional. Pelindungan teknologi keantariksaan sensitif merupakan inisiatif pribadi negara, dan lazimnya diatur dalam pengendalian ekspor.

Pengendalian ekspor (export control) merupakan pembatasan ekspor barang atau jasa yang diberlakukan oleh negara pengekspor. Pengendalian ini menekankan pada adanya jaminan kejelasan tujuan penggunaan akhir (end-use) dan pengguna akhir (end-user) dari teknologi sensitif

\footnotetext{
${ }^{3}$ Zainuddin Ali, Metode Penelitian Hukum, Sinar Grafika, Jakarta: 2014, hlm. 43.
} 
yang hendak diekspor tersebut. ${ }^{4}$ Saat ini terdapat beberapa rezim pengendalian ekspor, di antaranya adalah NSG, AG, MTCR, dan Wassenaar Arrangement. NSG merupakan perkumpulan negara pemasok nuklir yang berupaya untuk mengurangi persebaran senjata nuklir. AG merupakan forum informal negara-negara (dipelopori oleh Australia) untuk mengendalikan persebaran senjata kimia dan biologi. Wassenaar Arrangement adalah rezim kendali ekspor multilateral yang berupaya untuk mengendalikan transfer senjata konvensional, barang, dan teknologi guna ganda. ${ }^{5}$ Seluruh rezim tersebut sama-sama berperan dalam penyebaran teknologi keantariksaan sensitif, namun salah satu rezim yang kerap menjadi pembahasan adalah MTCR.

MTCR merupakan sebuah asosiasi informal yang memiliki kebijakan atau kepentingan dalam membatasi penyebaran misil beserta teknologinya. ${ }^{6}$ Tujuan MTCR adalah membatasi resiko penyebaran senjata pemusnah masal dengan cara mengendalikan perpindahan yang dapat berkontribusi pada sistem pengiriman senjata tersebut. ${ }^{7}$ Hingga saat ini MTCR memiliki anggota sebanyak 35 negara.

MTCR memiliki pedoman (guidelines) yang memuat prinsip-prinsip umum, serta lampiran (annex) yang menentukan teknologi tertentu yang dikendalikan. Daftar teknologi yang dikendalikan kemudian dibagi menjadi Kategori I dan II. Kategori I memuat seluruh sistem roket dan pesawat tanpa awak (termasuk rudal balistik, wahana peluncur, roket sonda, rudal jelajah, drone target, dan drone pengintaian) yang mampu mengirim muatan $>500 \mathrm{~kg}$ dengan kisaran jarak tempuh $>300$ $\mathrm{km}$, seluruh subsistem utamanya (tingkatan roket, mesin, set pedoman, dan kendaraan re-entry), perangkat lunak dan teknologi terkait, serta fasilitas yang didesain khusus untuk barang-barang tersebut. Barang-barang dalam kategori I tidak dapat dikirim ke negara pihak ketiga dan jarang dilisensi untuk eskpor terlepas dari tujuan ekspor tersebut. Sementara itu, kategori II memuat seluruh sistem roket dan pesawat tanpa awak yang tidak terdapat dalam kategori I dengan kemampuan capaian hingga atau $>300 \mathrm{~km}$. Berbeda dari Kategori I, negara-negara anggota dapat menyebarkan atau mengekspor barang-barang kategori II.

Terlepas dari cakupan pedomannya yang rinci, MTCR dan berbagai rezim lainnya adalah hukum lunak (soft law). Rezim ini harus diadopsi ke dalam hukum nasional negara anggotanya agar memiliki kekuatan hukum dan implementatif. Sub-bab selanjutnya akan membahas bagaimana negara anggota dan non-anggota menormakan rezim-rezim ini.

\footnotetext{
${ }^{4}$ Michael C. Mineiro, "An Inconvenient Regulatory Truth: Divergence in US and EU Satellite Export Control Policies in China", Space Policy, No. 4, Vol. 27, 2011, hlm. 217.

5 Rizky Roza, "Dual-Use Technology Jepang dan Kepentingan Keamanan Nasional Amerika Serikat", Jurnal Hubungan Internasional, Vol. I, No.2, 2012, hlm. 111-112.

${ }^{6}$ Siddhartha Sankar Manna, "Role of Missile Technology Control Regime (MTCR) in the World Politics (MTCR): An Overview", International Journal of Basic and Applied Research, No. 3, Vol. 9, 2019, hlm. 577.

7 Dini Susanti et al., Op.Cit. (Note 2), hlm. 76.
} 
Standar Pengaturan Pelindungan Teknologi Sensitif Keantariksaan Internasional: Implementasi di Indonesia

\section{Praktik Pengaturan Teknologi Sensitif Keantariksaan di Uni Eropa}

Peraturan pengendalian ekspor di Uni Eropa terdapat dalam Council Regulation (EC) No. 428/2009 of 5 May 2009 Setting up a Community Regime for the Control of Exports, Transfer, Brokering and Transit of Dual-Use Items. Regulasi ini secara umum memuat pengertian, lingkup kegiatan, daftar barang sensitif, hingga lisensi. Pada tahun 2017, lampiran dalam peraturan ini diamandemen melalui Commission Delegated Regulation (EU) 2017/2268.

Ketentuan umum yang terdapat dalam Regulasi 428/2009 terdiri dari makna guna ganda, teknologi, informasi, dan sebagainya. Pengertian guna ganda mencakup komponen, termasuk barang, perangkat lunak dan teknologi, yang dapat digunakan untuk tujuan sipil dan militer. ${ }^{8}$ Teknologi dimaknai sebagai informasi khusus yang diperlukan untuk pengembangan, produksi atau penggunaan barang. Adapun cakupan dari informasi meliputi data teknis (seperti panduan pengoperasian, cetak biru, rencana, diagram, dan model) maupun bantuan teknis (seperti instruksi, keterampilan atau pelatihan). ${ }^{9}$ Regulasi ini lebih lanjut mengelompokkan teknologi dari sisi peruntukkan, yaitu yang ditujukan untuk pemasangan, pengoperasian, pemeliharaan dan perbaikan barang yang disediakan. Keempat peruntukkan tersebut wajib memiliki izin ekspor. ${ }^{10}$

Empat aktivitas utama yang wajib tunduk pada peraturan ini adalah ekspor, transfer, perantara (brokering), dan transit barang guna ganda. Transfer mengatur perpindahan barang guna ganda di dalam Uni Eropa. Brokering merujuk pada segala aktivitas yang memfasilitasi pembelian, penjualan, atau transfer barang-barang penggunaan ganda yang nyata antara negara-negara ketiga. Transit merupakan kondisi di mana barang guna ganda masuk atau melintasi wilayah bea cukai Uni Eropa. ${ }^{11}$

Keterkaitan antara regulasi ini dengan teknologi keantariksaan terletak pada daftar barang sensitif. Daftar ini berfungsi untuk mengkategorikan jenis-jenis barang atau komponen yang wajib memperoleh lisensi. Lampiran 1 dikhususkan kepada kegiatan ekspor maupun brokering, sedangkan Lampiran 4 berlaku bagi perpindahan intra Uni Eropa. Apabila ada barang yang belum masuk dalam Lampiran 1, maka prinsip catch-all berlaku. ${ }^{12}$ Di sisi lain, barang yang sedang transit di Uni Eropa tidak perlu memperoleh lisensi, namun pihak berwenang dapat mewajibkan sebaliknya untuk kasus-kasus tertentu, seperti negara-negara yang diembargo Uni Eropa, Organisasi

\footnotetext{
8 Pasal 2 ayat (1) Council Regulation (EC) No. 428/2009 of 5 May 2009 Setting up a Community Regime for the Control of Exports, Transfer, Brokering and Transit of Dual-Use Items.

9 Ketentuan Umum Lampiran 1 Council Regulation (EC) No. 428/2009 of 5 May 2009 Setting up a Community Regime for the Control of Exports, Transfer, Brokering and Transit of Dual-Use Items.

${ }^{10}$ Quentin Michel, Veronica Vella, "The European Union Dual-Use Items Control Regime - Comment of the Legislation article-by-article", 2015, <http://www.esu.ulg.ac.be/file/20150812094802_Vademecum-DUV5Rev4.pdf>, [diakses pada 4/12/2019].

11 Ibid.

12 Pasal 4 Council Regulation (EC) No. 428/2009 of 5 May 2009 Setting up a Community Regime for the Control of Exports, Transfer, Brokering and Transit of Dual-Use Items.
} 
Keamanan dan Kerja Sama Uni Eropa, atau PBB. ${ }^{13}$

Lampiran 1 mencakup daftar barang yang terdapat dalam rezim pengendalian ekspor internasional seperti WA dan MTCR. Sebagai contoh, roket sonda jarak $300 \mathrm{~km}$, wahana peluncur, bus antariksa, beserta komponen, sistem dan struktur di dalamnya. Lampiran 4 memuat komponen dan barang yang dipandang sangat sensitif dalam hal potensi kontribusinya bagi pengembangan senjata pemusnah masal. Sama seperti lampiran sebelumnya, daftar barang di Lampiran 4 ini mencakup rezim-rezim seperti Kontrol Strategis Uni Eropa, MTCR, NSG, dan Konvensi Senjata Kimia. ${ }^{14}$

Regulasi ini memberlakukan tiga jenis perizinan yaitu, individu, global, dan umum. Lisensi individu diberikan kepada satu eksportir khusus atas satu atau beberapa barang guna ganda atau militer yang dikirimkan ke satu pengguna akhir. Lisensi global diberikan kepada satu eksportir khusus terhadap satu jenis atau kategori barang guna ganda, berlaku untuk ekspor ke satu atau lebih pengguna akhir yang ditentukan di satu atau lebih negara ketiga. Terdapat dua jenis lisensi umum: Otorisasi Ekspor Umum Uni Eropa (EUGEA) dan Otorisasi Ekspor Umum Nasional (NGEA). Keduanya menawarkan kepada para eksportir opsi untuk menggunakan prosedur yang telah disederhanakan untuk mengekspor secara eksklusif barang-barang penggunaan ganda ke negaranegara non-Eropa tertentu. EUGEA diterbitkan oleh Uni Eropa. EUGEA memiliki enam lisensi yang terdapat dalam Lampiran II-a hingga II-f. Sedangkan NGEA diterbitkan oleh masing-masing negara anggota. ${ }^{15}$

Secara umum, hal-hal yang diperhatikan dalam seluruh proses lisensi tersebut adalah: (i) kejelasan siapa pengguna akhir (end-user); (ii) negara yang dituju; dan (iii) kejelasan penggunaan akhir (end-use). Setelah itu pihak yang berwenang akan menilai dan mempertimbangkan apakah permohonan diterima atau tidak. Pertimbangan-pertimbangan tersebut terdiri dari pemenuhan kewajiban di bawah rezim non-proliferasi internasional yang relevan, pengaturan kontrol ekspor dan sanksi yang ada, embargo senjata, pertimbangan kebijakan luar negeri, keamanan nasional, pertimbangan penggunaan akhir yang dimaksudkan, hingga resiko pengalihan. ${ }^{16}$

Pada praktiknya, pertimbangan-pertimbangan tersebut tidak menjadi patokan mutlak karena negara-negara cenderung melakukan penilaian secara lebih rinci. Contohnya, Belanda melakukan penilaian resiko melalui analisis ex ante. Lebih lanjut mereka memiliki rangkaian pertanyaan yang harus dapat dijawab oleh pemohon saat melakukan pengajuan. Pertanyaan tersebut di antaranya

\footnotetext{
${ }^{13}$ Pasal 6 ayat (3) Council Regulation (EC) No. 428/2009 of 5 May 2009 Setting up a Community Regime for the Control of Exports, Transfer, Brokering and Transit of Dual-Use Items.

${ }^{14}$ Maximilian Trautinger, "The EU Export Control Regime on Outer Space Technologies", Seminar on Public International Law, Vienna: 2015, hlm. 19-21.

${ }^{15}$ Ibid., hlm. 22-23.

16 Ibid., hlm. 23-24.
} 
adalah: ${ }^{17}$

a) Informasi tentang negara tujuan akhir. Apakah negara tersebut merupakan bagian dari perjanjian dan rezim yang relevan? Apakah ia memiliki program senjata pemusnah masal yang aktif? Apakah ia memiliki rekam jejak yang baik tentang non-proliferasi?

b) Spesifikasi teknis barang. Apakah mereka cocok untuk penggunaan akhir yang dinyatakan? Untuk apa lagi mereka digunakan? Apakah ada alternatif (yang kurang sensitif)?

c) Informasi tentang pengguna akhir. Kegiatan apa yang dilakukan? Apakah pernah terlibat dalam kegiatan proliferasi yang sensitif?

d) Informasi tentang upaya akuisisi dari negara tujuan akhir. Apakah negara secara aktif mencari barang atau bagian tertentu?

e) Informasi tentang sifat transaksi, misalnya, bagaimana pesanan harus dipenuhi, mode transportasi yang diusulkan, negara yang akan dikunjungi selama pengiriman, mode pembayaran, broker yang terlibat.

f) Informasi dari kolega asing. Misalnya, penolakan lisensi dan presentasi di pertemuan rezim kontrol ekspor.

Dari penjabaran di atas, dapat disimpulkan bahwa Uni Eropa memiliki sistem pengaturan pengendalian teknologi yang sangat komprehensif. Definisi dan ruang lingkup teknologi guna ganda yang dilindungi sangat jelas, hal ini diperkuat dengan adanya daftar teknologi sensitif. Jenis-jenis kegiatan dan mekanisme perizinan juga disusun secara rinci. Selain itu, peraturan terkait pengendalian tersebut juga sesuai dengan kaidah rezim-rezim yang ada saat ini.

\section{Praktik Pengaturan Teknologi Sensitif Keantariksaan di Tiongkok}

Republik Rakyat Tiongkok merupakan negara maju yang tidak menjadi anggota WA, AG, maupun MTCR. Meski demikian, Tiongkok tetap memiliki rangkaian pengaturan pengendalian teknologi sensitif yang kerap disesuaikan dengan rezim-rezim tersebut. ${ }^{18}$

Dalam hierarki perundang-undangan Tiongkok, regulasi tertinggi tentang pengendalian ekspor terdapat dalam Bab 3 Foreign Trade Law. Kemudian, aturan khusus tentang ekspor teknologi keantariksaan sensitif terdapat dalam Regulations on Administration of Arms Export ("Regulasi Persenjataan") dan Regulations on Export Control of Missiles and Missile-related Items and Technologies ("Regulasi Misil”). Regulasi Persenjataan hanya berlaku untuk kegiatan militer dan pihak yang dapat mengajukan lisensi ekspor melalui aturan ini hanyalah perusahaan

\footnotetext{
17 Ministry of Foreign Affairs of the Kingdom of the Netherlands, "Export Control: User Guide on Strategic Goods and Services for The Netherlands", 2013, <https://www.sipri.org/sites/default/files/Netherlands-user-guide-on-strategic-goods-and-services-april-20131.pdf>, [diakses pada 24/3/2020].

${ }^{18}$ Yun Zhao, Yongmin Bian, "Export Control Regime for Space Items in China: Opportunities and Challenges in the New Era", Space Policy No.2, Vol. 27, 2011, hlm. 107.
} 
perdagangan misil. ${ }^{19}$

Regulasi Misil diundangkan pada tahun 2002 bersama dengan Daftar Pengendalian Ekspor Barang dan Teknologi Terkait Misil. Teknologi keantariksaan yang dikendalikan di antaranya adalah: (i) roket dalam setiap tahapnya; (ii) mekanisme antar-tahap untuk wahana peluncur dan perlengkapan yang secara khusus didesain untuk hal ini; (iii) motor roket dan perlengkapan yang secara khusus didesain untuk hal ini; (iv) desain teknologi untuk pengintegrasian panduan, kendali penerbangan, dan data propulsi ke dalam sistem manajemen penerbangan untuk optimalisasi trayek misil balistik atau wahana peluncur; dan (v) sistem navigasi satelit penyedia informasi perhitungan real-time posisi dan ketinggian in-flight. ${ }^{20}$ Pemohon lisensi dalam Regulasi Misil wajib terdaftar di Departemen Perdagangan Asing dan Kerja Sama Ekonomi. Selanjutnya departemen melakukan penilaian permohonan tersebut dan membuat keputusan dalam jangka waktu 45 hari setelah pengajuan diterima. ${ }^{21}$

Regulasi Misil mengatur tentang hukuman dan tanggung jawab kriminal untuk beberapa tindakan ilegal tertentu. ${ }^{22}$ Selain itu, Regulasi ini memberlakukan pendekatan presumption of denial, sertifikasi pengguna akhir dan penggunaan akhir, dan klausul catch-all. ${ }^{23}$

Terlepas dari sistem peraturannya yang komprehensif, Tiongkok mengalami penolakan ketika hendak bergabung dalam rezim pengendalian ekspor. Meskipun tidak diketahui penyebab resminya, beberapa peneliti memprediksikan beberapa kemungkinan. Pertama, kegiatan proliferasi Tiongkok dianggap kerap mengabaikan standar internasional terkait keamanan regional. ${ }^{24}$ Kedua, adanya kesenjangan daftar teknologi milik Tiongkok dengan daftar rezim internasional. Liu Jieyi menyatakan bahwa kesenjangan ini dapat disebabkan karena Tiongkok tidak memilikinya, atau karena barang tersebut tidak terpikirkan sebelumnya, atau karena para ahli tidak mengetahui secara jelas mengenai barang tersebut. ${ }^{25}$ Ketiga, adanya perbedaan sistem perizinan untuk kepentingan sipil dan militer. Meskipun pemerintah Tiongkok telah berupaya untuk menyelaraskan hal ini melalui pengesahan Measures on the Administration of Export Licenses on Dual Use Items and Technologies, dalam praktiknya hal ini tetap berpotensi menimbulkan masalah. ${ }^{26}$ Terakhir, belum adanya penegakan yang konkrit terutama dalam hal peninjauan lisensi dan persetujuan inspeksi di bea cukai. ${ }^{27}$ Walaupun penilaian perizinan dilakukan dengan sistem per kasus, ${ }^{28}$ apabila

\footnotetext{
${ }^{19}$ Yun Zhao, Yongmin Bian, Ibid., hlm. 109.

${ }^{20}$ Bagian I The Missiles and Missile-related Items and Technologies Control List 2002.

${ }^{21}$ Pasal 10 Regulations on Export Control of Missiles and Missile-related Items and Technologies 2002.

22 Pasal 18-22 Regulations on Export Control of Missiles and Missile-related Items and Technologies 2002.

${ }^{23}$ Pasal 16 Regulations on Export Control of Missiles and Missile-related Items and Technologies 2002.

${ }^{24}$ Shirley A. Kan, "China and Proliferation of Weapons of Mass Destruction and Missiles: Policy Issues", Congressional Research Service Report for Congress, United States: 2009, hlm. 46-47.

${ }^{25}$ Yun Zhao, Yongmin Bian, Op.Cit. (Note 18), hlm. 111.

26 Ibid.

27 Ibid.
} 
Standar Pengaturan Pelindungan Teknologi Sensitif Keantariksaan Internasional: Implementasi di Indonesia

dibandingkan dengan negara-negara Uni Eropa (dhi. Belanda), regulasi Tiongkok belum menunjukkan adanya mekanisme penilaian yang konkrit.

Penjabaran di atas menunjukkan bahwa kerangka peraturan yang lengkap saja tidak cukup meyakinkan dunia internasional. Negara-negara, terutama non-anggota rezim multilateral, ditantang untuk tidak hanya menyusun kerangka hukum, tetapi juga memberlakukan sistem, prosedur dan sanksi yang aplikatif.

\section{Peraturan Pengendalian Ekspor Teknologi Sensitif di Indonesia}

Indonesia bukan anggota rezim pengendalian ekspor manapun. Indonesia berpendirian bahwa rezim menghambat akses negara berkembang terhadap teknologi yang sebenarnya ditujukan untuk maksud damai. ${ }^{29}$ Meski demikian, Indonesia memiliki sejumlah regulasi nasional terkait pengendalian ekspor, di antaranya adalah: (i) Undang-Undang Nomor 16 Tahun 2012 tentang Industri Pertahanan; (ii) Undang-Undang Nomor 10 Tahun 1997 tentang Energi Nuklir; (iii) Undang-Undang Nomor 9 Tahun 2008 tentang Penggunaan Bahan Kimia dan Larangan Penggunaan Bahan Kimia Sebagai Senjata Kimia; (iv) Peraturan Pemerintah Nomor 29 Tahun 2008 tentang Perizinan Pemanfaatan Sumber Radiasi Pengion dan Bahan Nuklir; dan (v) Peraturan Kementerian Dalam Negeri 23/M-DAG/PER/9/2011 tentang Pengadaan, Distribusi dan Pengawasan Bahan Berbahaya.

Kerangka regulasi pengendalian ekspor tersebut memuat elemen seperti daftar barang yang dikendalikan, perizinan, dan mekanisme di bea cukai. Meski demikian, kumpulan peraturan perundang-undangan tersebut tidak memuat ketentuan terkait teknologi keantariksaan.

Undang-Undang Nomor 21 Tahun 2013 tentang Keantariksaan merupakan sumber hukum utama dalam kegiatan keantariksaan di Indonesia. Di dalamnya terdapat pasal terkait teknologi sensitif keantariksaan termasuk penjaminan keamananny ${ }^{30}$ serta standar dan prosedur kemanan dan keselamatannya. ${ }^{31}$ Butir-butir pasal tersebut kemudian diamanatkan untuk diatur ke dalam Peraturan Pemerintah.

\section{Pelindungan Teknologi Sensitif dalam RPP Penguasaan Teknologi Keantariksaan}

Sama seperti dua negara sebelumnya, RPP Penguasaan Teknologi Keantariksaan juga memuat definisi guna ganda. Namun, peristilahan yang digunakan adalah teknologi sensitif. Kemudian, "pelindungan" merupakan upaya mewujudkan keselamatan dan keamanan dalam

\footnotetext{
${ }^{28}$ The Federal Office for Economic Affairs and Export Control (BAFA), Handbook on Export Control of Dual-Use Items and Related Technologies in China, The Federal Office for Economic Affairs and Export Control (BAFA), Germany: 2012, hlm. 13.

${ }^{29}$ Andy Rachmianto, "Indonesia's Approach to Strategic Trade Controls: The Perspective of a Developing and Archipelagic Country", Strategic Trade Research, No. 2, Vol. 2, 2016, hlm. 130.

${ }^{30}$ Pasal 27 Undang-Undang Nomor 21 Tahun 2013 tentang Keantariksaan.

${ }^{31}$ Pasal 57 Undang-Undang Nomor 21 Tahun 2013 tentang Keantariksaan.
} 
penguasaan teknologi keantariksaan untuk menjamin keberlanjutan kegiatan keantariksaan, serta melindungi negara dan warga negaranya dari dampak negatif yang ditimbulkan. ${ }^{32}$ Pelindungan bermuara pada upaya untuk menjamin keamanan teknologi sensitif keantariksaan yang masuk (atau diimpor) ke wilayah kedaulatan dan wilayah yurisdiksi Indonesia. Penjaminan tersebut dilakukan melalui penyusunan daftar teknologi sensitif keantariksaan, pemberian izin impor, serta pengendalian impor teknologi sensitif keantariksaan. ${ }^{33}$ Jaminan ini sekilas hampir sama dengan praktik di negara-negara.

RPP ini mengatur penyusunan daftar teknologi sensitif keantariksaan untuk menegakkan pengendalian impor dan mengawasi penggunaannya di wilayah Indonesia. ${ }^{34}$ Lembaga wajib melibatkan Kementerian/Lembaga terkait dalam proses penyusunan daftar tersebut. Namun demikian, RPP ini belum memuat apa saja barang, komponen, dan teknologi yang dikategorikan sensitif. RPP ini hanya membatasi motor roket sebagai komponen yang hanya dapat dikuasai dan dikembangkan oleh Lembaga, kecuali pihak tersebut memperoleh izin dari Lembaga. ${ }^{35}$ RPP ini mendelegasikan untuk menyusun daftar ini dalam Peraturan Lembaga.

Pengimpor teknologi keantariksaan sensitif mengajukan permohonan izin kepada Kepala LAPAN dengan menyertakan permohonan tertulis dan memenuhi persyaratan izin. Persyaratan tersebut terdiri dari persyaratan administratif, persyaratan teknis, dan persyaratan finansial.

Pasal 27 menjabarkan persyaratan administratif terdiri dari bukti pendirian badan hukum, sertifikat penerapan sistem manajemen keselamatan dan kesehatan kerja dari Kementerian Ketenagakerjaan, serta perizinan impor dan/atau ekspor dari Kementerian Perdagangan dan Kementerian Keuangan. Kemudian, Pasal 28 ayat (1) menyebutkan persyaratan teknis meliputi dokumen keamanan proliferasi, dokumen rencana dan tujuan penggunaan, dokumen kepemilikan pengguna dan pengguna akhir, dokumen analisis keamanan dan keselamatan, serta dokumen batasan dan kondisi operasi. Selanjutnya, Pasal 29 menyatakan bahwa persyaratan finansial wajib dipenuhi oleh badan hukum yang menyelenggarakan kegiatan keantariksaan. Persyaratan ini dipenuhi dengan menyertakan bukti kemampuan finansial pertanggungjawaban kerugian akibat kegiatan keantariksaan.

Pengendalian bertujuan untuk memastikan bahwa teknologi sensitif keantariksaan yang diimpor hanya dipergunakan sesuai peruntukan awal dan oleh pengguna akhir. ${ }^{36}$ Pengendalian dilaksanakan oleh Lembaga khusus terhadap impor teknologi sensitif keantariksaan. Langkahlangkah pengendalian yang dilakukan oleh Lembaga adalah: (i) melakukan inspeksi secara berkala

\footnotetext{
32 Pasal 1 butir 6 Rancangan Peraturan Pemerintah tentang Penguasaan Teknologi Keantariksaan.

33 Pasal 20 ayat (4) Rancangan Peraturan Pemerintah tentang Penguasaan Teknologi Keantariksaan.

34 Pasal 22 Rancangan Peraturan Pemerintah tentang Penguasaan Teknologi Keantariksaan.

${ }^{35}$ Pasal 8 ayat (2) Rancangan Peraturan Pemerintah tentang Penguasaan Teknologi Keantariksaan.

${ }^{36}$ Pasal 38 ayat (2) Rancangan Peraturan Pemerintah tentang Penguasaan Teknologi Keantariksaan.
} 
Standar Pengaturan Pelindungan Teknologi Sensitif Keantariksaan Internasional: Implementasi di Indonesia

atau sewaktu-waktu sepanjang pengajuan permohonan izin dan/atau masa berlakunya izin, dengan atau tanpa pemberitahuan; (ii) memasuki dan memeriksa setiap fasilitas dan/atau kawasan tempat teknologi sensitif keantariksaan berada, kecuali bagi fasilitas/kawasan milik instansi pemerintah lainnya maka Lembaga perlu melakukan koordinasi dahulu; (iii) meminta laporan pada penyelenggara keantariksaan selain Lembaga terkait dengan impor dan/atau pemanfaatan teknologi sensitif keantariksaan yang diimpor. ${ }^{37}$

Standar dan prosedur keamanan mencakup sarana dan prasarana, bahan baku dan komponen, lingkungan, personil, kegiatan, dan transportasi. ${ }^{38} \mathrm{Hal}$ ini penting untuk menjamin keamanan penyelenggaraan keantariksaan. Meski demikian, standar yang ditetapkan dalam RPP ini masih bersifat umum. Hal ini dikarenakan standar keamanan antara teknologi roket, satelit, dan aeronautika hanya memiliki sedikit perbedaan yang kurang signifikan. Aspek-aspek utama standar keamanan dalam RPP ini di antaranya adalah: (i) adanya jaminan ketelusuran penggunaan dan perpindahan sarana prasarana serta bahan baku dan komponen; (ii) pembatasan akses ke sarana prasarana, bahan baku dan komponen; dan (iii) pengoperasian hanya dapat dilaksanakan oleh ahli yang memiliki sertifikat dari Lembaga atau Instansi lain. Di luar ketiga aspek tersebut, terdapat beberapa standar lainnya, namun tidak ada kaitannya dengan pelindungan teknologi sensitif.

Berbagai pembahasan di atas secara tidak langsung menunjukkan adanya sebuah pola pengaturan pelilndungan teknologi keantariksaan sensitif yang berlaku di negara-negara, yaitu: (i) konsep pelindungan teknologi; (ii) penerapan rezim pengendalian ekspor internasional; (iii) daftar teknologi sensitif keantariksaan dan prinsip catch-all; (iv) perizinan dan penilaian; serta (v) pengawasan. Aspek-aspek inilah yang membentuk kerangka regulasi pelindungan teknologi keantariksaan sensitif di negara-negara. Pemenuhan terhadap aspek-aspek tersebut pula yang menentukan apakah negara-negara maju bersedia untuk mengirimkan teknologi keantariksaannya ke negara lain. Berangkat dari kerangka standar regulasi tersebut, perbandingan kesesuaian RPP Penguasaan Teknologi Keantariksaan akan dilakukan.

\section{Analisis terkait Konsep Pelindungan Teknologi Sensitif Keantariksaan}

Unsur pertama yang menjadi perhatian adalah bagaimana konsep pelindungan teknologi sensitif keantariksaan yang dipraktikkan negara-negara. Berdasarkan standar praktik yang ada, konsep pelindungan teknologi keantariksaan sensitif sama-sama merupakan upaya suatu negara untuk melindungi teknologi beserta komponen di dalamnya dari penyalahgunaan oleh pihak eksternal. Tujuan akhir dari pelindungan ini sesungguhnya adalah keamanan internasional.

\footnotetext{
${ }^{37}$ Pasal 38 ayat (3) Rancangan Peraturan Pemerintah tentang Penguasaan Teknologi Keantariksaan.

${ }^{38}$ Pasal 42 Rancangan Peraturan Pemerintah tentang Penguasaan Teknologi Keantariksaan.
} 
Pengendalian ekspor merupakan wujud nyata konsep tersebut.

Philippe Achilleas menyatakan bahwa rezim hukum pengendalian ekspor merupakan perpaduan antara hukum perdagangan internasional dan hukum keamanan internasional. ${ }^{39}$ Pernyataan ini sejalan dengan prinsip dalam Traktat mengenai Prinsip-Prinsip yang Mengatur Kegiatan Negara-Negara dalam Eksplorasi dan Penggunaan Antariksa, termasuk Bulan dan BendaBenda Langit Lainnya 1967 (“Traktat Antariksa 1967”). Penyalahgunaan teknologi keantariksaan sensitif dapat membahayakan keamanan internasional dan melanggar ketentuan dalam perjanjian antariksa internasional. Kedua potensi bahaya tersebut diatur dalam Pasal III dan IV Traktat Antariksa 1967. Selain itu, konsep pelindungan yang serupa juga diadopsi secara internasional melalui Resolusi Dewan Keamanan PBB 1540 tahun 2004.

Di sisi lain, nuansa pelindungan teknologi dalam RPP Penguasaan Teknologi Keantariksaan mengacu pada alih teknologi. Hal ini mengakibatkan arah pelindungan teknologi dalam RPP ini kepada kegiatan impor. Mengingat rezim pengendalian ekspor merupakan hal yang krusial dalam alih teknologi, RPP ini berusaha menjembatani kegiatan impor dan ekspor. Elemen-elemen seperti pernyataan end-use dan end-user terdapat dalam materi muatannya. Meski demikian, pengintegrasian kedua elemen tersebut belum dapat menjamin negara pengekspor bahwa teknologinya tidak akan disalahgunakan. Suatu negara tidak hanya wajib untuk memiliki regulasi pengendalian ekspor yang komprehensif, tetapi juga harus memiliki struktur penegakan hukum (enforcement) yang jelas. ${ }^{40}$ Penegakan hukum memperkuat konsep pelindungan dan keamanan teknologi keantariksaan untuk mencapai tujuan akhirnya.

RPP Penguasaan Teknologi Keantariksaan jelas bukanlah sebuah regulasi pengendalian ekspor teknologi keantariksaan karena tidak ada pasal yang mengatur perihal tersebut. Selain itu, RPP ini juga belum mengatur mekanisme pelaksanaan pengendalian alih teknologi secara rinci. Dengan demikian, dalam aspek ini masih terdapat kesenjangan atau perbedaan konsep pelindungan teknologi sensitif antara standar negara-negara dengan Indonesia.

\section{Analisis terkait Penerapan Rezim Pengendalian Ekspor Internasional}

Regulasi pengendalian ekspor di tingkat nasional umumnya berkiblat kepada rezim pengendalian ekspor internasional terlepas dari status keanggotaannya. Tiongkok bukan anggota MTCR, namun pada praktiknya mereka tetap mengelaborasikan prinsip rezim tersebut. Hal ini menjadi fenomena unik karena rezim pengendalian ekspor bukanlah sebuah instrumen hukum

\footnotetext{
${ }^{39}$ Philippe Archilleas, "Introduction Export Control", dalam: Dai Tamada dan Philippe Archilleas (eds), Theory and Practice of Export Control: Balancing International Security and International Economic Relations, Springer, Singapore: 2017, hlm. 4.

${ }^{40}$ Stephanie Lieggi, "From Proliferator to Model Citizen? China's Recent Enforcement of Nonproliferation-Related Trade Controls and its Potential Positive Impact in the Region”, Strategic Studies, No. 2, Vol. 4, 2010, hlm. 47.
} 
Standar Pengaturan Pelindungan Teknologi Sensitif Keantariksaan Internasional: Implementasi di Indonesia

yang memiliki kekuatan mengikat. Rezim baru akan memiliki kekuatan hukum apabila suatu negara mengadopsi rezim tersebut baik dengan menjadi negara anggota atau melalui legislasi nasionalnya. ${ }^{41}$ Bagaimana suatu rezim yang merupakan hukum lunak dapat mempengaruhi negaranegara?

Bila dikaitkan dengan teori rezim, Krasner menekankan bahwa rezim bukanlah sebuah pengaturan yang bersifat sementara, melainkan jangka panjang. ${ }^{42}$ Jill Stuart menambahkan bahwa meskipun rezim tidak dinormakan, tetapi kekuatan dan pengaruhnya dapat melebihi hukum tertulis. Selama sebuah rezim mendapat internalisasi yang meluas, maka rezim tersebut dapat diformalkan menjadi hukum. ${ }^{43}$

Dari sisi teori rezim hukum, penormaan politik menjadi sebuah regulasi adalah hal yang biasa. Menurut teori ini, hukum menjadi alat untuk melihat pengaruh suatu negara atau pemerintahan terhadap negara lain sampai ke sistem hukumnya. ${ }^{44}$ Apabila melihat pola dalam MTCR, maka Amerika Serikat merupakan negara yang perannya sangat dominan dibandingkan dengan negara anggota lain. Amerika Serikat memberi sanksi kepada negara-negara (baik anggota maupun bukan) yang mengirimkan teknologinya ke negara yang dianggap berbahaya bagi Amerika Serikat. ${ }^{45}$ Hukuman tersebut umumnya berupa larangan bagi negara pelanggar untuk menandatangani kontrak, menerima bantuan, atau membeli persenjataan dari Pemerintah Federal Amerika Serikat selama dua tahun atau lebih. ${ }^{46}$ Meskipun sanksi ini hanya terdapat dalam hukum domestik, pada praktiknya negara-negara MTCR kerap memperhatikan sanksi ini karena "memberikan pertimbangan kepatuhan terhadap hukum nasional Amerika Serikat" merupakan salah satu tersebut dasar awal dalam menjadi negara anggota MTCR. ${ }^{47}$ Sehingga, hukum nasional Amerika Serikat secara tidak langsung turut mempengaruhi kekuatan rezim MTCR, dan negara lain tidak memiliki pilihan lain akibat posisi Amerika Serikat yang kuat.

Rezim pengendalian ekspor sudah dikembangkan sejak lama oleh negara-negara anggotanya. Meskipun tidak pernah disusun dalam bentuk perjanjian multilateral, negara anggota tetap mematuhi aturan tersebut dan mengaturnya ke dalam hukum nasionalnya masing-masing. Terlepas dari kentalnya pengaruh politik suatu negara dalam sebuah rezim, negara-negara

\footnotetext{
${ }^{41}$ Johannes Rath (et.al.), "Evolution of Different Dual-use Concepts in International and National Law and Its Implications on Research Ethics and Governance", Science and Engineering Ethics, No.3, Vol. 20, 2014, hlm. 771.

${ }^{42}$ Stephen D. Krasner," Structural Causes and Regime Consequences: Regimes as Intervening Variables", International Organization, No. 2, Vol. 36, 1982, hlm. 187.

43 Jill Stuart, "Regime Theory and the Study of Outer Space Politics" 2013, <https://www.e-ir.info/2013/09/10/regime-theory-and-thestudy-of-outer-space-politics/>, [diakses pada 20/9/2020].

${ }^{44}$ William Hurst, Ruling Before the Law, Cambridge University Press, United Kingdom: 2018, hlm. 28.

${ }^{45}$ Ghazala Yasmin Jalil, "India's Membership of Missile Technology Control Regime: Implications for South Asia”, Strategic Studies, No. 3 Vol. 37, hlm. 44.

${ }^{46}$ International Business Publications, Arms Control and International Security Policy Handbook: Strategic Information and Developments, International Business Publications, Washington D.C: 2012, hlm. 296.

${ }^{47}$ Mallory Stewart, "Are Treaties Always Necessary? How U.S. Domestic Law Can Give Teeth to Non-Binding International Commitments", Proceedings of the Annual Meeting (American Society of International Law), Washington D.C.: 2010 , hlm. 191.
} 
cenderung tetap mengikuti rezim tersebut karena kebutuhan dan lain sebagainya. Bahkan negara non-anggota seperti Tiongkok pun mengikuti pola rezim yang ada. Fakta ini dapat dipengaruhi oleh minimnya pemilik teknologi keantariksaan, sedangkan kebutuhan terhadap teknologi sangat tinggi. Rezim pengendalian ekspor secara nyata memvalidasi teori rezim dan teori rezim hukum. Negaranegara rela untuk patuh pada rezim, sehingga terjadi internalisasi yang meluas dan sanksi dari Amerika Serikat menjadi sangat penting dalam rezim tersebut. Negara-negara menjadi sangat berhati-hati dalam menyebarkan teknologinya, dan akibatnya, rezim pengendalian ekspor turut memberi dampak pada negara ketiga.

Dalam praktiknya, negara-negara cenderung menggabungkan lebih dari satu rezim ke dalam peraturan nasionalnya. Beberapa kemungkinan penyebabnya adalah, selain karena negara tersebut menjadi pihak di dua rezim atau lebih (dhi. negara-negara Uni Eropa), negara tersebut juga bertekad untuk membentuk sebuah kerangka hukum yang tidak hanya komprehensif tetapi juga implementatif. Contohnya, Tiongkok mengelaborasikan rezim NSG dan WA ke dalam regulasinya, serta mengimplementasikan MTCR sebagai pedoman daftar teknologi keantariksaan sensitifnya. Semua ini dilakukan Tiongkok untuk menunjukkan tekad kuatnya untuk dapat diterima oleh negara-negara anggota rezim. ${ }^{48}$

RPP Penguasaan Teknologi Keantariksaan tidak merujuk pada satu rezim manapun. Selain karena faktor politik internasional, ${ }^{49}$ pasal-pasal di dalamnya memang kurang mengakomodir konsep pengendalian ekspor. Seperti telah dibahas sebelumnya, RPP ini hanya mengadopsi konsep end-use dan end-user tanpa ada mekanisme lanjutannya yang mendetail. Oleh karena itu, dalam aspek ini terdapat kesenjangan pula antara praktek negara-negara dengan Indonesia.

\section{Analisis terkait Daftar Teknologi Sensitif Keantariksaan dan Prinsip "Catch-All”}

Praktik menunjukkan bahwa cakupan teknologi keantariksaan sensitif yang dikendalikan sudah tercermin mulai dari bagian ketentuan umum, dan kemudian diperjelas melalui daftar teknologi yang dikendalikan. Umumnya negara-negara menggabungkan daftar pengendalian dari berbagai rezim untuk kemudian dielaborasikan dalam daftar pengendalian nasionalnya. Sebagaimana dicontohkan oleh Uni Eropa dan Tiongkok, daftar ini lazimnya terlampir bersamaan dengan regulasi terkait kegiatan ini, bukan diatur melalui peraturan tersendiri. Selain itu, apabila pengekspor mengetahui atau sepatutnya mengetahui bahwa barang atau teknologi yang hendak mereka kirim akan secara langsung digunakan untuk mengembangkan misil atau sistem senjata pemusnah masal oleh penerima, maka pengekspor wajib mengajukan lisensi meskipun barang yang

\footnotetext{
${ }^{48}$ Yun Zhao, Yongmin Bian, Loc.Cit.

${ }^{49}$ Andy Rachmianto, Loc.Cit.
} 
Standar Pengaturan Pelindungan Teknologi Sensitif Keantariksaan Internasional: Implementasi di Indonesia

dimaksud tidak terdapat dalam daftar. Prinsip ini disebut dengan pengendalian "catch-all". 50 Prinsip ini diterapkan oleh Uni Eropa dan Tiongkok. Meski demikian, ruang lingkup kendali "catchall" lazimnya tergantung pada kebijakan masing-masing Negara. ${ }^{51}$

Ketentuan umum dalam RPP Penguasaan Teknologi Keantariksaan telah mendefinisikan "teknologi sensitif". Namun, definisi tersebut belum mencerminkan cakupan yang rinci mengenai jenis teknologi seperti apa yang dikatakan sensitif. Uni Eropa mendefinisikan dan mengelompokkan teknologi apa saja yang dinyatakan guna ganda dalam bagian ketentuan umumnya, sehingga memperjelas ruang lingkup teknologi itu sendiri. Indonesia dapat mencontoh praktik Uni Eropa dengan merubah definisi "teknologi sensitif" di bagian ketentuan umumnya, atau menerapkan sistem pengelompokan yang serupa dalam penyusunan daftar teknologi sensitif.

Selanjutnya, daftar teknologi sensitif keantariksaan merupakan isu yang unik dalam RPP ini. Pasal 20 ayat (4) RPP menyebutkan perihal daftar teknologi. Kemudian, Pasal 22 RPP ini menekankan urgensi daftar teknologi sebagai jaminan penegakan pengendalian impor dan sebagai fungsi pengawasan. RPP ini juga menekankan bahwa daftar ini menjadi komponen integral dalam perizinan kegiatan impor teknologi keantariksaan. ${ }^{52}$ Namun, alih-alih melampirkan daftar tersebut, RPP ini mengamanatkan bahwa daftar ini akan diatur dalam Peraturan Lembaga. ${ }^{53}$ Walaupun dari segi perundang-undangan hal ini lazim karena daftar ini bersifat teknis, namun dari sisi pelaksanaan hal ini kurang implementatif karena kelak RPP ini harus menunggu Peraturan Lembaga tersebut disahkan untuk menjalankan fungsinya secara penuh. Selain itu, mengingat Peraturan Lembaga/Menteri juga harus melalui tahap harmonisasi dengan Kementerian/Lembaga terkait lainnya, tentunya "waktu tunggu" ini akan lebih lama dari sebelumnya. Sedangkan untuk pengendalian "catch-all", RPP ini belum mengatur prinsip tersebut. Dengan demikian, RPP Penguasaan Teknologi Keantariksaan masih memiliki kesenjangan dari standar cakupan teknologi, daftar teknologi, dan penerapan prinsip "catch-all" yang dipraktikkan pada umumnya.

\section{Analisis terkait Perizinan dan Penilaian}

Perizinan merupakan aspek esensial dalam kegiatan keantariksaan. Pasal VI Traktat Antariksa 1967 mewajibkan negara untuk mengotorisasi kegiatan keantariksaan warganya melalui sebuah perizinan atau lisensi. Izin berfungsi sebagai alat untuk menjaga para penyelenggara keantariksaan untuk tetap berada dalam koridor Traktat Antariksa 1967 dan menjamin keamanan aktivitas

\footnotetext{
50 Yun Zhao, Yongmin Bian, Op.Cit. (Note 18), hlm. 110.

${ }^{51}$ Fabian Bohnenberger, "The Proliferation of Cyber-Surveillance Technologies: Challenges and Prospects for Strengthened Export Controls", Strategic Trade Review, No. 4, Vol. 3, 2017, hlm. 98.

52 Pasal 24 Rancangan Peraturan Pemerintah tentang Penguasaan Teknologi Keantariksaan.

53 Pasal 21 ayat (2) Rancangan Peraturan Pemerintah tentang Penguasaan Teknologi Keantariksaan.
} 
tersebut. ${ }^{54}$ Perizinan juga menjadi kerangka hukum fundamental dalam regulasi pengendalian ekspor. Terlepas dari adanya perbedaan perihal jenis-jenis lisensi yang dikeluarkan, umumnya negara-negara menekankan pada sertifikasi end-use dan end-user sebagai syarat utama perizinan.

Praktik juga menunjukkan adanya pertimbangan-pertimbangan non-teknis dalam menerbitkan izin. Dalam menilai permohonan perizinan, negara-negara menerapkan metode yang menjadi standar dalam rezim-rezim yang berlaku. Meskipun hal ini tidak disebutkan secara konkrit dalam regulasinya, namun mengingat Uni Eropa merupakan anggota dari berbagai rezim, maka tentu dalam praktiknya mereka berkewajiban mengikuti standar rezim tersebut. Hal ini terbukti dalam praktik di Belanda. Sedangkan Tiongkok dalam pedomannya mengaku telah memiliki prosedur penilaian yang ketat. ${ }^{55}$

Hal serupa juga dipraktikkan dalam RPP Penguasaan Teknologi Keantariksaan. Indonesia saat ini mengatur mengenai izin impor teknologi keantariksaan. Selain itu, RPP ini juga menyebutkan berbagai persyaratan yang harus dipenuhi oleh pemohon dan penilaian teknis. ${ }^{56}$ Meski demikian, Indonesia perlu mulai mempertimbangkan metode seperti apa yang diterapkan dalam meninjau permohonan perizinan. Hal ini dikarenakan Indonesia bukanlah anggota dari rezim manapun. Pelajaran yang dapat diambil dari pengalaman Tiongkok adalah terlepas dari kelengkapan sistem hukum nasionalnya, statusnya yang bukan anggota rezim tetap menjadi penghambat. Ketika suatu negara menjadi anggota rezim, maka negara tersebut dianggap telah memiliki dan akan mengikuti sistem yang terstandar dalam rezim tersebut. ${ }^{57}$ RPP Penguasaan Teknologi Keantariksaan saat ini hanya berkiblat kepada persyaratan teknis, administratif, dan finansial dalam melakukan penilaian teknis. ${ }^{58}$ Oleh karena itu, perlu ada penambahan terkait sistem penilaian dan metode yang akan diterapkan dengan rinci.

\section{Analisis terkait Pengawasan}

Salah satu peraturan teknis lainnya yang secara implisit dipraktikkan oleh negara-negara adalah sistem pengawasan top-down yang menyeluruh. Kewajiban untuk melakukan pengawasan yang berkelanjutan juga diamanatkan oleh Pasal VI Traktat Antariksa 1967. Amanat ini berkaitan dengan tanggung jawab negara secara internasional dalam kegiatan keantariksaan. Gerhard menyatakan bahwa pengawasan yang dimaksud bukan hanya sebelum kegiatan berlangsung, tetapi mencakup seluruh durasi program tersebut. Negara wajib menyediakan upaya memadai untuk menerima informasi, serta upaya lainnya untuk mengintervensi atau mencegah dan

\footnotetext{
${ }^{54}$ Michael Gerhard, "Article VI", dalam: Hobe, Schimdt-Tedd, Schrogl, Cologne Commentary on Space Law Volume I, Carl Heymanns Verlag, Germany: 2009, hlm. 117.

55 The Federal Office for Economic Affairs and Export Control (BAFA), Op.Cit. (Note 28), hlm. 32.

${ }^{56}$ Pasal 31 ayat (1) dan (2) Rancangan Peraturan Pemerintah tentang Penguasaan Teknologi Keantariksaan.

57 Stephen D. Krasner, Op.Cit. (Note 42), hlm. 191.

58 Pasal 32 ayat (1) Rancangan Peraturan Pemerintah tentang Penguasaan Teknologi Keantariksaan.
} 
menghukum. ${ }^{59}$

Rezim pengendalian ekspor seperti Wassenaar Arrangement memiliki mekanisme pengawasan dua arah di mana perusahaan eksportir wajib untuk turut melakukan pengawasan dan melaporkan kegiatannya kepada Instansi berwenang secara rutin. Mekanisme tersebut adalah Internal Compliance Program (ICP). Uni Eropa ${ }^{60}$ dan Tiongkok ${ }^{61}$ menerapkan sistem ini.

Pengawasan dalam konteks RPP terdapat dalam sub-bab mengenai pengendalian impor teknologi sensitif keantariksaan. Upaya pengendalian yang dilakukan di antaranya adalah inspeksi secara berkala atau sewaktu-waktu, pemeriksaan fasilitas dan/atau kawasan tempat teknologi tersebut berada, dan meminta laporan pada penyelenggara keantariksaan selain Lembaga terkait dengan impor dan/atau pemanfaatan teknologi sensitif keantariksaan yang diimpor. Menurut hemat penulis, langkah-langkah tersebut sudah baik. Namun, ada baiknya apabila RPP ini membangun sistem penilaian mandiri seperti ICP di mana penyelenggara keantariksaan memiliki mekanisme pengendalian dan pengawasan sendiri dan terpadu, sehingga tujuan pelindungan teknologi sensitif keantariksaan tercapai secara nyata

\section{PENUTUP}

Regulasi pelindungan teknologi keantariksaan sensitif di negara-negara merupakan suatu sistem peraturan yang sarat akan rezim pengendalian ekspor dan sarat akan detail teknis yang sebaiknya tidak luput untuk diatur. Hasil komparasi pada pembahasan menunjukkan bahwa standar pengaturan tersebut setidaknya terdiri dari: (i) konsep pelindungan teknologi; (ii) penerapan rezim pengendalian ekspor internasional; (iii) daftar teknologi sensitif keantariksaan dan prinsip catch-all; (iv) perizinan dan penilaian; serta (v) pengawasan.

RPP Penguasaan Teknologi Keantariksaan secara prinsipil membantu memperkuat dan memperluas sistem pelindungan teknologi sensitif nasional ke bidang teknologi keantariksaan. Meski demikian, masih terdapat kesenjangan antara rancangan regulasi di Indonesia dengan standar peraturan negara-negara. Apabila dibandingkan dengan praktek negara-negara, pelindungan teknologi keantariksaan sensitif kerap terintegrasi dengan sistem pengendalian ekspornya secara keseluruhan, sedangkan di Indonesia konsep pelindungan teknologi hanya sebatas pengendalian impor. Materi muatan dalam RPP Penguasaan Teknologi Keantariksaan juga masih belum mencerminkan adanya sistem pengendalian dan pengawasan yang rinci. Selain itu, fakta bahwa keanggotaan rezim pengendalian ekspor menjadi jaminan utama bagi negara-negara maju dan riwayat kegiatan persenjataan suatu negara tidak dapat dipungkiri. Meski demikian,

\footnotetext{
${ }^{59}$ Michael Gerhard, Op.Cit. (Note: 54), hlm. 119-120.

${ }^{60}$ European Commission Joint Research Center, Strengthening Strategic Export Controls by Internal Compliance Programmes. Second Revision, Publications Office of the European Union, Luxembourg: 2014, hlm. 4.

${ }^{61}$ The Federal Office for Economic Affairs and Export Control (BAFA), Op.Cit. (Note 28), hlm. 50.
} 
Indonesia memiliki peluang lebih besar dibanding Tiongkok untuk memperoleh teknologi-teknologi tersebut mengingat Indonesia belum memiliki pelanggaran internasional terkait persenjataan, sehingga Indonesia hanya perlu memperkuat kerangka hukumnya untuk mencapai amanat penguasaan teknologi. Dalam rangka menjembatani kesenjangan tersebut, maka hal-hal yang sebaiknya ditambahkan ke dalam RPP Penguasaan Teknologi Keantariksaan adalah:

1. Memperjelas ruang lingkup teknologi sensitif di bagian Ketentuan Umum, atau menerapkan pengelompokan teknologi yang komprehensif dalam daftar teknologi keantariksaan sensitif.

2. Melampirkan daftar teknologi keantariksaan sensitif yang dikendalikan sebagai satu kesatuan dengan RPP.

3. Menambahkan ketentuan mengenai pengendalian "catch-all".

4. Menambahkan sub-bab khusus mengenai klasifikasi dan batasan jelas mengenai end-use dan end-user. Termasuk di dalamnya larangan untuk melakukan ekspor kembali (re-export). Hal ini tidak hanya dapat memperkuat metode penilaian perizinan, tetapi juga dapat memperkuat jembatan antara impor dan ekspor.

5. Menciptakan kewajiban pelaksanaan pengawasan dan pengendalian mandiri kepada penyelenggara keantariksaan selain Lembaga atau ICP. Hal ini dilengkapi dengan standar dan prosedur yang telah ditentukan oleh Lembaga. Hasil pengawasan dan pengendalian ini tentunya wajib dilaporkan kepada Lembaga secara periodik, atau dapat dimintakan sewaktu-waktu oleh Lembaga.

6. Memperkuat sistem pengawasan dan pengendalian tersebut melalui penerapan sanksi. Sanksi tersebut meliputi peringatan tertulis, denda, sanksi administratif, hingga sanksi pidana bila diperlukan.

Kemudian, terlepas dari urgensi dan kondisinya saat ini, ke depannya Indonesia perlu mempertimbangkan untuk menyusun sistem pengendalian ekspor khusus teknologi keantariksaan. Sistem ini tidak hanya memperkuat posisi RPP ini, tetapi juga menjadi jaminan yang lebih solid di tingkat internasional. 
Standar Pengaturan Pelindungan Teknologi Sensitif Keantariksaan Internasional: Implementasi di Indonesia

\section{DAFTAR PUSTAKA}

Buku

Dai Tamada dan Philippe Archilleas (eds), Theory and Practice of Export Control: Balancing International Security and International Economic Relations, Springer, Singapore: 2017.

European Commission Joint Research Center, Strengthening Strategic Export Controls by Internal Compliance Programmes. Second Revision, Publications Office of the European Union, Luxembourg: 2014.

Hobe, Schimdt-Tedd, Schrogl, Cologne Commentary on Space Law Volume I, Carl Heymanns Verlag, Germany: 2009.

Husni Nasution, Euis Susilawati, Mardianis (eds), Kajian Kebijakan Penerbangan dan Antariksa, In Media, Bogor: 2018.

International Business Publications, Arms Control and International Security Policy Handbook: Strategic Information and Developments, International Business Publications, Washington D.C: 2012.

The Federal Office for Economic Affairs and Export Control (BAFA), Handbook on Export Control of Dual-Use Items and Related Technologies in China, The Federal Office for Economic Affairs and Export Control (BAFA), Germany: 2012.

William Hurst, Ruling Before the Law, Cambridge University Press, United Kingdom: 2018.

Zainuddin Ali, Metode Penelitian Hukum, Sinar Grafika, Jakarta: 2014.

\section{Jurnal}

Andy Rachmianto, “Indonesia's Approach to Strategic Trade Controls: The Perspective of a Developing and Archipelagic Country", Strategic Trade Research, No. 2, Vol. 2, 2016.

Cassandra Steer, "Global Commons, Cosmic Commons: Implications of Military and Security Uses of Outer Space", Georgetown Journal of International Affairs, No. 1, Vol. 18, 2017.

Fabian Bohnenberger, "The Proliferation of Cyber-Surveillance Technologies: Challenges and Prospects for Strengthened Export Controls", Strategic Trade Review, No. 4, Vol. 3, 2017.

Ghazala Yasmin Jalil, "India's Membership of Missile Technology Control Regime: Implications for South Asia", Strategic Studies, No. 3 Vol. 37, 2017.

Johannes Rath (et.al.), "Evolution of Different Dual-use Concepts in International and National Law and Its Implications on Research Ethics and Governance", Science and Engineering Ethics, No.3, Vol. 20, 2014.

Michael C. Mineiro, "An Inconvenient Regulatory Truth: Divergence in US and EU Satellite Export Control Policies in China", Space Policy, No. 4, Vol. 27, 2011. 
Rizky Roza, "Dual-Use Technology Jepang dan Kepentingan Keamanan Nasional Amerika Serikat", Jurnal Hubungan Internasional, No.2, Vol. I, 2012.

Siddhartha Sankar Manna, "Role of Missile Technology Control Regime (MTCR) in the World Politics (MTCR): An Overview", International Journal of Basic and Applied Research, No. 3, Vol. 9, 2019.

Stephanie Lieggi, "From Proliferator to Model Citizen? China's Recent Enforcement of Nonproliferation-Related Trade Controls and its Potential Positive Impact in the Region", Strategic Studies, No. 2, Vol. 4, 2010.

Stephen D. Krasner, "Structural Causes and Regime Consequences: Regimes as Intervening Variables", International Organization, No. 2, Vol. 36, 1982.

Yun Zhao, Yongmin Bian, "Export Control Regime for Space Items in China: Opportunities and Challenges in the New Era", Space Policy No.2, Vol. 27, 2011.

\section{Peraturan Perundang-Undangan}

Foreign Trade Law of the People's Republic of China 2004.

Regulations on Export Control of Missiles and Missile-related Items and Technologies 2002.

The Missiles and Missile-related Items and Technologies Control List 2002.

Council Regulation (EC) No. 428/2009 of 5 May 2009 Setting up a Community Regime for the Control of Exports, Transfer, Brokering and Transit of Dual-Use Items.

Undang-Undang Nomor 21 Tahun 2013 tentang Keantariksaan.

\section{Sumber Lain}

Jill Stuart, "Regime Theory and the Study of Outer Space Politics" 2013, <https://www.eir.info/2013/09/10/regime-theory-and-the-study-of-outer-space-politics/>, [diakses pada 20/9/2020].

Mallory Stewart, “Are Treaties Always Necessary? How U.S. Domestic Law Can Give Teeth to NonBinding International Commitments", Proceedings of the Annual Meeting (American Society of International Law), Washington D.C.: 2010.

Maximilian Trautinger, "The EU Export Control Regime on Outer Space Technologies", Seminar on Public International Law, Vienna: 2015.

Ministry of Foreign Affairs of the Kingdom of the Netherlands, "Export Control: User Guide on Strategic Goods and Services for The Netherlands", 2013, <https://www.sipri.org/sites/ default/files/Netherlands-user-guide-on-strategic-goods-and-services-april-2013-1.pdf>, [diakses pada 24/3/2020]. 
Standar Pengaturan Pelindungan Teknologi Sensitif Keantariksaan Internasional: Implementasi di Indonesia

Quentin Michel, Veronica Vella, "The European Union Dual-Use Items Control Regime-Comment of the Legislation article-by-article", 2015, <http://www.esu.ulg.ac.be/file/ 20150812094802_Vademecum-DUV5Rev4.pdf>, [diakses pada 4/12/2019].

Rancangan Peraturan Pemerintah tentang Penguasaan Teknologi Keantariksaan, versi Mei 2019.

Shirley A. Kan, "China and Proliferation of Weapons of Mass Destruction and Missiles: Policy Issues", Congressional Research Service Report for Congress, United States: 2009. 